\title{
How to Paint Nothing? : Pictorial Depiction of Levinasian il y a in Vilhelm Hammershøi's Interior Paintings
}

\section{Mäcklin, Harri Mikael}

2018

Mäcklin , H M 2018 , ' How to Paint Nothing? Pictorial Depiction of Levinasian il y a in

Vilhelm Hammershøi's Interior Paintings ' , Journal of Aesthetics and Phenomenology, vol. 5 , no. 1 , pp. 15-29 . https://doi.org/10.1080/20539320.2018.1460112

http://hdl.handle.net/10138/308520

https://doi.org/10.1080/20539320.2018.1460112

unspecified

acceptedVersion

Downloaded from Helda, University of Helsinki institutional repository.

This is an electronic reprint of the original article.

This reprint may differ from the original in pagination and typographic detail.

Please cite the original version. 


\title{
How to Paint Nothing?
}

\section{Pictorial depiction of Levinasian il y a in Vilhelm Hammershøi's interior paintings}

\author{
Harri Mäcklin \\ A esthetics \\ D epartment of Philosophy, History and Art Studies \\ University of Helsinki \\ P.O. Box 59 (Unioninkatu 38), 00014 University of Helsinki, Finland \\ $+358503257281$ \\ harri.macklin@ helsinki.fi
}

\begin{abstract}
Contemporary phenomenological discussions on relationship between painting and nothingness have mainly employed Sartrean and Heideggerian notions of nothingness. In this article, I propose another perspective by discussing the possibility of pictorially depicting Levinas's notion of the nothingness of being, which he develops in his early works in terms of the il y a ("there is").

For Levinas, the il y a intimates itself in moments like insomnia, where the world as a horizon of possibilities slips away and all there is left is an experience of present absence, an enchainment to the night, which renders the insomniac utterly impotent and exposed. The possibility of eliciting an experience of the il y a through artistic means has been extensively discussed in literary theory, but so far there has been hardly any discussion regarding the pictorial depiction the il y a. In this article, I suggest that the atmospheric interior paintings of the D anish artist Vilhelm Hammershøi (1864-1916) exemplify par ex œllenœ a painterly rendering of the experience of Levinasian nothingness. Through an analysis of Hammershøi's compositional techniques, I show how figurative means can bring about an anonymous, non-figurative presence which eludes reification.
\end{abstract}

Keywords: Nothingness, il y a, painting, Emmanuel Levinas, Vilhelm Hammershøi

Biographical note: Harri Mäcklin is a doctoral student in aesthetics at the University of Helsinki. He is currently finishing his $\mathrm{PhD}$ thesis $\mathrm{G}$ oing E lsewhere. A Phenomenology of A esthetic Immersion, which develops a systematic phenomenology of aesthetic immersion using perspectives from hermeneutic and existential phenomenology. He also works as an art critic in the daily newspaper Helsingin Sanomat. harri.macklin@helsinki.fi

Acknowledgement: This work was supported by the D octoral School of Philosophy, Arts and Society, University of Helsinki 


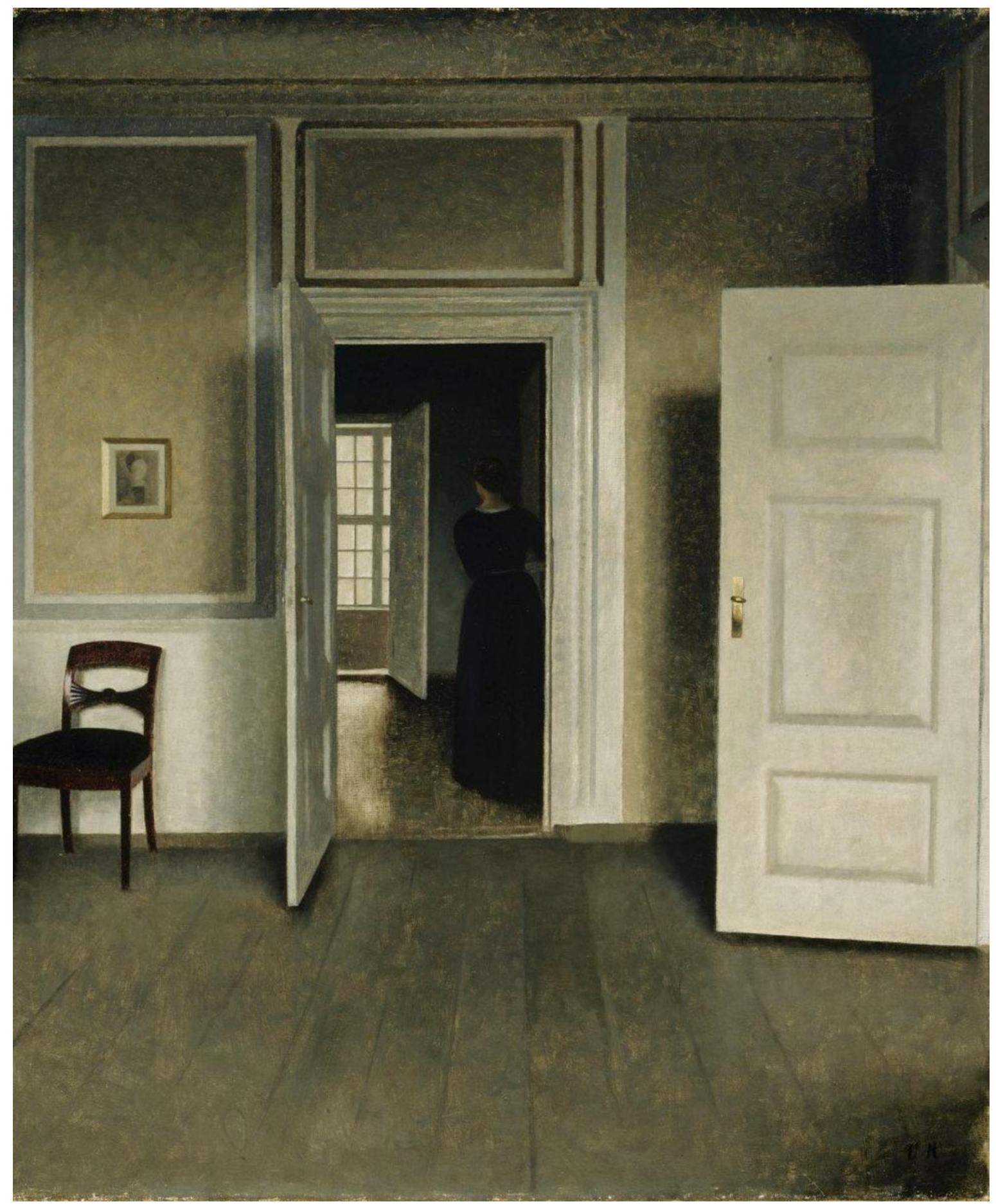

Fig. 1

Vilhelm Hammershøi, Interior from the H ouse of the A rtist, c. 1900

Oil on canvas

(c) Finnish National Gallery / Hannu Aaltonen

CC0 1.0 Universal (CC0 1.0) Public Domain Dedication 


\section{Introduction}

On the $20^{\text {th }}$ of February 1976, Emmanuel Levinas held a lecture titled "How to Think Nothingness?" as a part of his lecture series D eath and Time (L a mort et le temps, published in D ieu, la mort et le temps, 1993). There Levinas argued that even if nothingness intimates itself in various experiences of anxiety and horror, its refractory and unthematizable character eludes philosophical grasp. The very structure of intentionality, the fact that consciousness is always turned toward something, makes it impossible to intentionally aim at nothing. "Nothingness has defied Westem thought," Levinas concluded. ${ }^{i}$ However, despite its refractory character - or perhaps precisely because of it - nothingness has been a recurrent theme in $20^{\text {th }}$ century phenomenology, and as an outcome one can approach it from several perspectives, ranging from Sartre's notion of nothingness as the negation of being to Levinas's own notion of nothingness as the irremissible fullness of being.

In this article, I wish to inquire that if nothingness defies thinking, would it nevertheless be possible to paint it? Could something as utterly invisible and immaterial as nothingness be captured in the concreteness of paint? To be more precise, what would it mean to paint nothingness in the sense Levinas himself understands it, as the il y a? In asking this, I wish to widen the phenomenological discussion concerning the pictorial depiction of nothingness, which has so far primarily employed Sartrean and Heideggerian perspectives. The Levinasian il y a has been extensively discussed in relation to literature by Maurice Blanchot and his commentators, but the discussion on the pictorial depiction of the il y a has remained non-existent. I wish to suggest some ways in which the experience of the il y a can be brought about with pictorial means by interpreting the interior painting of the Danish painter Vilhelm Hammershøi (1864-1916), one of the best known Scandinavian painters.

I will first briefly outline some examples of the Sartrean and Heideggerian perspectives in which the relationship between painting and nothingness has been discussed. Then I will introduce Levinas's notion of the il y a in some depth, and finally discuss the enigmatic, oppressive atmosphere of Hammershøi's interiors, which, as I will argue, is best understood precisely in terms of the il y a. Through a detailed analysis of Hammershøi's compositional techniques, I aim to show how figurative means can evoke an experience of a modality of presence which eludes reification.

\section{Grasping nothing}

The relationship between painting and nothingness has not been at the forefront of phenomenological discussions, even if both art and nothingness have gained much attention in existential phenomenology. To contextualise my interpretation of Levinas and Hammershøi, I will first briefly outline some aspects 
of the literature that does exist. The perspectives on the pictorial depiction of nothingness come, roughly, in three forms, one of which comes from Sartre and two from Heidegger.

In Being and $\mathrm{N}$ othingness (L 'Ê tre et le néant, 1943) Jean-Paul Sartre understands nothingness in terms of a negation which consciousness brings into existence. ${ }^{\text {i. }}$ Consciousness, the for-itself, is essentially a power of negation by which consciousness is able to set itself apart from the world (and from itself, for that matter). In other words, consciousness as intentional activity is possible only because it can sever, or nihilate, the plenitude of being into non-identical phenomena, thus inserting nothingness into the midst of being. Jeffrey Weiss has interpreted Mark Rothko's paintings in terms of this Sartrean nothingness, arguing that they stage a similar "double negation" as Pierre's absence in the famous section of Being and N othingness: in the same way as Pierre's absence makes Sartre, who seeks him, identify everything in the café as notPierre and experience the whole place filled by this absence, Rothko's paintings perform a nihilation, where consciousness is unable to fathom any figures, and the remaining colour fields are consequently haunted by a presence of absence.ii

Martin Heidegger's thinking affords not one but two ways of thinking about nothingness. The first of these is the discussion in Being and Time (Sein und Z eit, 1927) on the nothingness of death, in the face of which the finitude and contingency of Dasein's existence are disclosed. ${ }^{\text {iv }}$ In anxiety, D asein is forced out of the inauthentic They (das M an), into which D asein escapes in an attempt to evade the burden of assuming its unique and finite self, and forced to face the possibility of death, which it cannot outstrip. In this experience of the slipping-away of the world, Heidegger argues, nothingness intimates itself. For Heidegger, this experience is not necessarily a crippling one but profoundly empowering: in resolutely facing its impending nothingness, D asein assumes its authentic self as a unique "ability-to-be" and thus takes responsibility for its finite existence. ${ }^{v}$ Natalie Kosoi has argued that it is precisely this experience, and not the Sartrean variety, which is staged in Rothko's paintings. ${ }^{\text {vi }}$ According to Kosoi, the dynamics of Rothko's colour fields visually represent the slipping-away of the world, forbidding us from distinguishing any figures in them and thus making sense of them as constellations of meaning. These hovering, indistinct shapes "undermine our ability to read the colors of the forms depicted in his paintings as well as the space in which they are situated," thus enacting the collapse of the everyday world in an experience of anxiety. ${ }^{\text {vii }}$ Kosoi argues that in this way Rothko's paintings "intimate mortality" and force us to face our unique ability-to-be in the face of this painted nothingness. ${ }^{\text {viii }}$

The second Heideggerian interpretation stems from the period following Being and Time. Before Heidegger came up with the vocabulary of his later thinking, nothingness was one of the terms he began to use to denote the aspect of concealment and withdrawal embedded in the process of unconcealment, or the disclosure of meaningful presence. ${ }^{\text {ix }}$ In this development, nothingness no longer denotes the 
nothingness of death, but the nothingness inherent to being itself, the necessary background against which presence becomes possible. Iain Thomson has argued that Heidegger's discussion of Van Gogh's shoe painting in the Introduction to M etaphysics (E infuhrung in die M etaphysik, 1935) and The Origin of the W ork of A rt (D er Ursprung des Kunstwerkes, 1935-36) aims to articulate this dynamic relationship between nothingness and presence. ${ }^{x}$ Though Heidegger himself is not explicit on this matter, Thomson argues that Heidegger's insistent use of enigmatic formulations such as "Surrounding this pair of farmer's shoes there is nothing" and "A pair of farmer's shoes and nothing more" betray his interest in the way the indistinct background of the painting and the depicted shoes illustrate the rising of presence from nothingness. Thus, in Thomson's interpretation, Heidegger approaches the relationship between painting and nothingness not in terms of the painting's ability to induce anxiety, but in terms of its capacity of staging the process by which the $O$ pen is constituted. ${ }^{\text {i }}$

In sum, the three main perspectives concerning the pictorial depiction of nothingness conceive nothingness as 1) the negation of being, 2) the nothingness of death, and 3) nothingness as the element of concealment. In the following, I wish to take up a fourth notion, one very different to the ones mentioned: the Levinasian il y a.

\section{Nothing that remains}

In the lecture series $D$ eath and $T$ ime Levinas makes the following comparison between two forms of nothingness:

In death, as pure nothingness, as foundationlessness - which we feel more dramatically, with the acuteness of that nothingness that is greater in death than in the idea of nothingness of being (in the there is [il y a], which wounds less than disappearance does) - we arrive at something that European philosophy has not thought.xii

The lectures themselves are devoted to the "pure nothingness" of death and leave out the latter form, the "nothingness of being," the il y a. However, it is precisely this form of nothingness that interests me in this article.

The il y a is a major preoccupation in Levinas's early writings, especially in Time and the 0 ther (Le temps et l'autre, lecture series held in 1946-47) and E xistenœe and E x istents (D e l'ex istenœ à l'ex istant, 1947). Already at this stage of his career, before the radical othemess of the other person gains centre stage in his thinking, Levinas is preoccupied with the paradox that will animate his whole philosophical oeuvre. Would it be possible to think phenomenologically of something that strictly speaking never enters the order of phenomenality? Could one describe, while staying true to phenomenology, something that exceeds the limits of phenomenology? The problem of the il y a represents Levinas's early encounter with this paradox. 
In contrast to Sartre and Heidegger, for whom nothingness signifies a dimension of being that withdraws from presence while acting as its constitutive part, for Levinas nothingness as the il y a denotes paradoxically the insistence of being that remains even when every existent thing is removed from the world. The il y a is thus an anonymous, formless, and indeterminable presence tucked away under the entities that clutter my world. In Time and the 0 ther, Levinas introduces the notion by way of a thought experiment:

Let us image all things, beings and persons, returning to nothingness. Do we encounter pure nothingness? What remains after this imaginary destruction of everything is not something, but the fact that there is [il y a]. The absence of everything returns as a presence, as the place where the bottom has dropped out of everything, an atmospheric density, a plenitude of the void, or the murmur of silence. There is, after this destruction of things and beings, the impersonal "field of forces" of existing. There is something that is neither subject nor substantive. The fact of existing imposes itself when there is no longer anything. [... ] It is the irremissibility of existing.xiii

In Levinas's early work this experience gains the name il y a. As William Large has pointed out, the vanishing of the world and self into nothingness should not be understood categorically as an actual disappearance, but rather as an existential mood akin to Heideggerian anxiety: it is an experience that affects the very way the subject exists. ${ }^{\text {xiv }}$ Since this experience has to do with a presence that cannot be reified or aimed at in any intentional act, Levinas takes up a strategy that brings him to the very limits of phenomenology. In a way reminiscent of the later Levinas, who describes the trace of the other's face through an indirect phenomenology, where its radical otherness is approached "by situating it with respect to the phenomenology it interrupts, ${ }^{{ }^{\prime \prime v}}$ the early Levinas describes the il y a through the way it disturbs our quotidian ways of existing. This description can be broken down into the following elements.

$\mathrm{H}$ aunting presence. In everyday life, we are usually absorbed in the activity that consumes our attention. The world offers me shelter and refuge by succumbing to my needs and sustaining me, becoming something

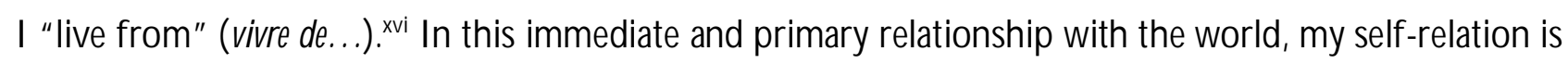
unreflective: I can escape from myself to the world which nourishes me. ${ }^{\text {xvi }}$ However, there are times, like in the midst of insomnia - Levinas's favourite example - when the world turns against me. In the dead of night, when sleep escapes me, I am stripped of the possibility of fleeing from my predicament and rendered impotent in the suffocating embrace of the night. ${ }^{\text {xviii }}$ Everything slips into darkness, yet something remains: the night itself watches. ${ }^{\text {xix }}$ The world becomes uncanny and filled with an ominous, oppressing presence, "like a field of forces, like a heavy atmosphere belonging to no one." ${ }^{\mathrm{xx}}$ This presence estranges me from my world, which no longer facilitates dwelling and offers no refuge. There is only silence, but this silence is no emblem of peace: "nothing approaches, nothing comes, nothing threatens; this silence, this tranquillity, this void of sensations constitutes a mute, absolutely indeterminate menace," Levinas writes and continues: "There is no determinate being, anything can count for anything else. In 
this ambiguity the menace of the pure and simple presence, of the there is, takes form." "xxi This is what Levinas means by nothingness - an anonymous presence that cannot be assigned to anything, a no-thingness - which has to be distinguished from the "pure" nothingness of death:

The horror of the night, as an experience of the thereis, does not then reveal to us a danger of death, nor even a danger of pain. That is what is essential in this analysis. The pure nothingness revealed by anxiety in Heidegger's analysis does not constitute the there is. There is horror of being and not anxiety over nothingness, fear of being and not fear for being; there is being prey to, delivered over to something that is not a 'something.' When night [sic] is dissipated with the first rays of the sun, the horror of the night is no longer definable. The "something" appears to be "nothing." xxii

Solitude. For Levinas, the everyday world is always shared with others: it is the very presence of the other that opens the possibility of being in contact with the outside world. In the experience of the night, these intersubjective ties are severed. The subject, "in participating the there is, finds itself again to be a solitude, in the definitiveness of the bond with which the ego is chained to itself." xxiii Part of the il y a's acuteness lies in the very impotence by which I become unable to save myself from its paralysing presence. Time and again Levinas will argue that there are no possibilities I might assume to save myself; it is only the other that can dissipate the il y a and salvage me from my suffering. .xiv $^{\text {. }}$

Passivity. The horror of insomnia lies in the fact that I cannot escape it. The night strips me of the possibility of evasion, and I find myself chained to the night like Prometheus to his rock, utterly exposed and unable to take shelter. The il y a suspends my ability-to-be, that is, my ability to transcend my interiority and project myself towards the world, and unearths a more primordial, passive layer of subjectivity. Stripped of the possibility of assuming my possibilities, I become "a vigilance without possible recourse to sleep," ${ }^{x x v}$ pure exposure to anonymous, passive being. In these moments I am overtaken, as Kris Sealey says, by "a feeling of being an existent, no longer (or rather, not yet) a locus of possibility, but instead, a vulnerability under the burden of having to exist." "xxvi The il y a reduces my subjectivity to pure nakedness preceding the ability-to-be, which defines Heideggerian D asein. This way the Levinasian experience of nothingness differs in crucial ways from Heidegger's empowering anxiety, which opens the possibility for D asein to affirm its authentic existence. For Levinas, the il y a is an experience of utter passivity and impotence, which oppresses rather than liberates:

Being toward death, in Heidegger's authentic existence, is a supreme lucidity and hence a supreme virility. It is D asein's assumption of the uttermost possibility of existence, and consequently makes possible the very feat of grasping a possibility - that is, it makes possible activity and freedom. Death in Heidegger is an event of freedom, whereas for me the subject seems to reach the limit of the possible in suffering. It finds itself enchained, overwhelmed, and in some way passive.xxvii

Breakdown of intentionality and the interior-exterior-divide. The absorption into everyday activities, the very movement by which I move outside myself, is by nature intentional: I direct my attention to this or that activity and choose the objects to which I attach myself. Such intentional activity is precisely a movement 
outwards, a transcending of my interiority towards the exterior, which offers me "a shelter and buffer" from my enchainment to myself. xxviii The il y a, however, offers no such refuge. Since the presence of the il y a is not localizable to any object, it thwarts intentionality: there is nothing exterior in the night toward which I could aim my attention. I become subject to the night, and not the other way round. This incapability of immersing oneself into anything exterior turns one towards their interiority, or, to be more precise, breaks down the very distinction between interiority and exteriority:

There is transcends inwardness as well as exteriority; it does not even make it possible to distinguish these. The anonymous current of being invades, submerges every subject, person, or thing. The subject-object distinction by which we approach existents is not the starting point for a mediation which broaches being in general.xxix

In other words, the unreflective self-mediation, which characterises everyday intentionality, is reversed so that I become all too acutely aware of myself as being chained to the night. This self-presence cannot be readily distinguished from the oppressive presence of the night itself - as William Large says, "my interiority is turned inside out like a glove." ${ }^{\prime x x}$

E ncapsulation of time. Finally, the experience of the il y a is for Levinas very much tied to the experience of time. In the dead of night, the clock ticks, but time does not move: I find myself riveted to an encapsulated instant, which is pure duration without future, and all I can do is wait. xxxi Behind this description lies Levinas's insistence that temporality is not the achievement of a solitary subject, but a dimension afforded only in and through intersubjectivity: time is the gift of the other. ${ }^{\text {xxxi }}$ The only thing the solitary subject can give themselves is an instant (l'instant), which lacks ecstatic openness to the future. ${ }^{\text {xxxii }}$ Since the il y a severs intersubjective bonds, it is also a closure of time proper: the subject is chained to the instant, frozen in futureless duration without exit.

\section{Rooms full of nothing}

The relationship between the il y a and art has been widely discussed in the context of literature, especially since Blanchot made the experience of the il y a a central theme in his literary theory. ${ }^{\text {xxiv }}$ Here I am interested in whether the il y a could be evoked through pictorial depiction. Would it be possible to transform the physical medium of paint and canvas into an evocation of a presence which eludes reification?

Levinas's own writings suggest that there might be a relationship between the il y a and painting (and art in general), but these remarks are somewhat ambiguous, and they need to be discussed in some other instance. ${ }^{\mathrm{xxv}}$ Instead, let me turn to some concrete examples, which in my view confirm the possibility of pictorially evoking the il y a. In the following, I aim to show how the il y a can be found from the most unlikely of places: a quaint bourgeois apartment in the heart of Copenhagen. 
Vilhelm Hammershøi is perhaps most famous for his interior paintings, most of which depict his apartment on Copenhagen's Strandgade 30. Interiors of bourgeois homes became a fashionable genre in D enmark's art scene in the 1880's, and before Hammershøi painters like Peter Ilsted and Carl Holsøe had already popularised the genre of ascetic depictions of women's everyday life. ${ }^{\text {xxvi }}$ However, what sets Hammershøi apart from his contemporaries is the way he strips his interiors of all anecdotal material, refrains from social commentary, and uses his apartment as a source of painterly experimentation on light, space, and geometric compositions. xxxvii Though his oeuvre does entail a significant amount of portraits, landscapes, and Copenhagen's cityscapes, I shall limit my discussion to his interior paintings, since it is in them that this omission gains its most pressing phenomenological effect.

My aim in the following analysis is not to speculate anything about Hammershøi's personal intentions, or otherwise impose upon the paintings a symbolising reading. Indeed, Poul Vad and Görel CavalliBjörkman have both warned against the temptation of seeking some deeper symbolic or esoteric meaning in Hammershøi's atmospheric interiors, simply because he saw himself as painting the home he loved and aimed to capture merely "the visible and the concrete" (det synlige og konk rete) and paint "the phenomenology of elements" (elementens fænomenologi).xxviii By delving into the way Hammershøi paints the visible and the concrete, I aim to show that he also manages to paint a mode of presence that exceeds the visible and the concrete - the nothingness of the il y a. In other words, I will discuss how, paradoxically, Hammershøi brings out something radically non-figurative using solely figurative means.

My main claim is that it is precisely Hammershøi's rendering of the utterly invisible and non-concrete by staying firmly within the plane of the visible and concrete that opens a new vista for the thinking of painting's relationship to nothingness. In contrast to Van Gogh's shoes and Rothko's colour fields, Hammershøi's interiors are outside the logic of transition between the figurative and the abstract, upon which earlier phenomenological discussions on painting and nothingness depend. What I wish to suggest is that precisely by staying strictly on the figurative plane, Hammershøi can intimate absence in the heart of presence instead of painting absence in opposition to presence.

On the face of it, Hammershøi's interiors are very traditional, representational images of an apartment and its puritan décor. And yet - the rooms feel somehow deserted, devoid of life, and haunted by an almost tangible sense of absence. The silence of the rooms is wrought with tension, a feeling of foreboding, as if something was about to happen any minute. But nothing ever happens: the interiors close in on themselves, frozen in eternal tranquillity of a Sunday afternoon, whose motionless quietude begins to border on claustrophobia. Time stands still. Only dust particles dance in the sunbeams. A solitary figure, a woman dressed black (modelled after the painter's wife Ida), sometimes lingers in the rooms, often with her back facing the viewer, but she remains distant, unreachable, enclosed within 
herself. It would be pushing it too far to describe the paintings in the dramatic way Levinas speaks of the horrors of the night - and yet, there is something haunting, oppressive, and unnerving in them that is very similar to the Levinasian experience of the il y a. It is this connection I wish to pursue further in this article.

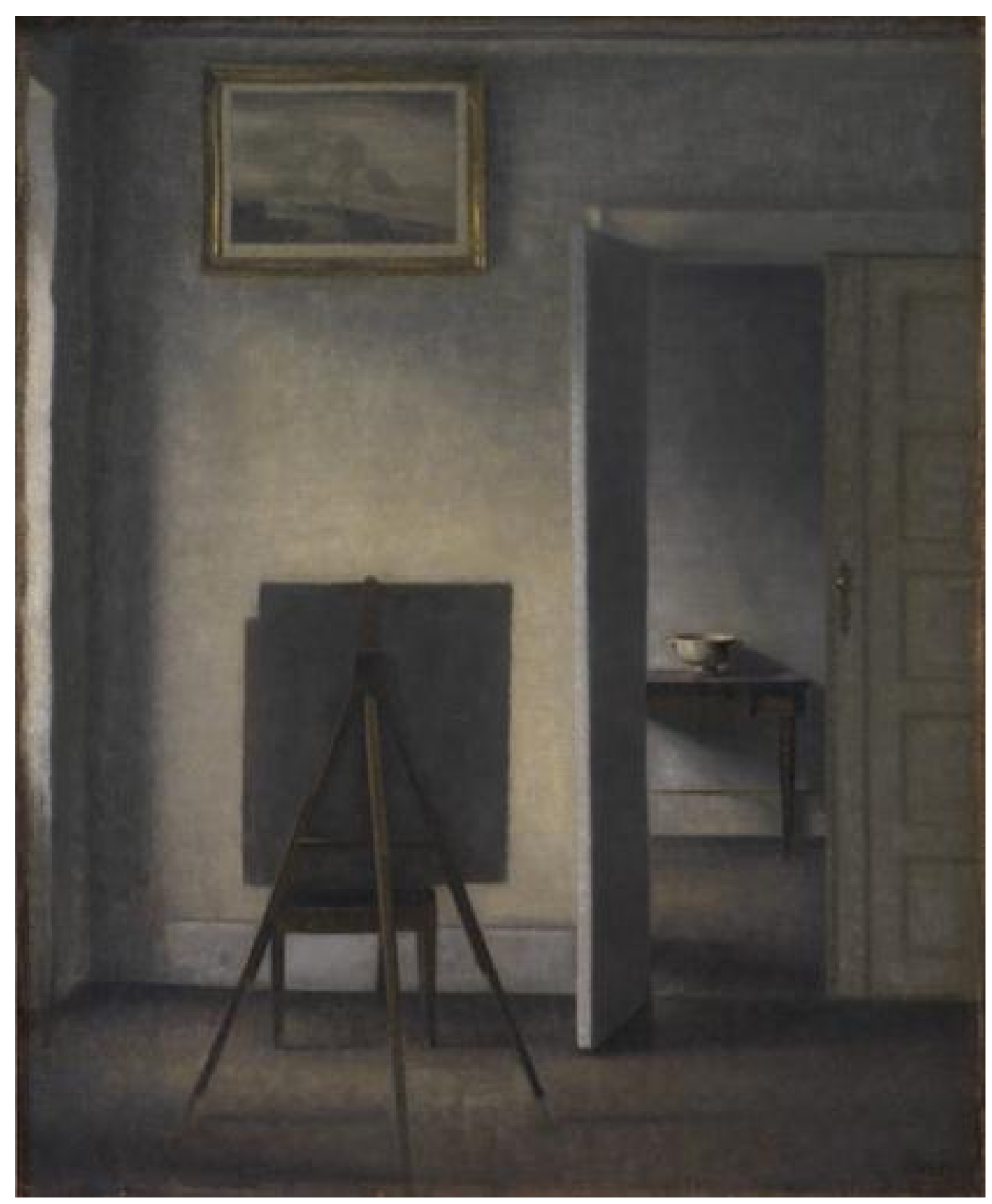

Fig. 2

Vilhelm Hammershøi: Interior with the A rtist's E asel, 1910

Oil on canvas

Statens Museum for Kunst, Denmark

CC0 1.0 Universal (CC0 1.0) Public Domain Dedication 
Hammershøi is often described as a painter of silence. ${ }^{\text {xxxix }}$ While I do agree on the point that silence plays a crucial role in his paintings, this must be qualified further. There are, after all, many different sorts of silence: think of the tranquil silence of nature in midsummer twilight, the tragic silence of funerals, or the awkward silence that disrupts a conversation. The silence in Hammershøi's interiors is an enigmatically oppressive and suffocating form of silence, which opens them to a Levinasian interpretation. In the following, I will trace some essential ways in which Hammershøi's compositional techniques achieve their effect. My main aim is to show how these pictorial means, despite being wholly figurative, have a similar effect on the viewer as the night on the insomniac, thus evoking an impersonal and haunting presence analogous, if not identical, to the Levinasian il y a.

Pidorial space. The single most crucial element in the overall effect of Hammershøi's interiors is the construction of the pictorial space itself. Here the painter employs two compositional strategies, which together form an illusion of an enclosed void. Firstly, the objects in the interiors, mostly furniture, are usually pushed against the walls and away from the viewer's vantage point, so that the pictorial space comprises of an uninterrupted void. Yet the way Hammershøi depicts the apartment is marked with an acute sense of claustrophobia, as if the apartment was shut tight and enclosed from the outside world. Hammershøi achieves this effect primarily by the use of doors and windows. The doors, usually closed or half open, never offer a passage outside; at best, they open onto another room, like a Chinese puzzle box (see Fig. 1). If the viewer's gaze is allowed to go beyond the room closest to the viewer's vantage point, the gaze is trumped from reaching the outside world by a closed door or a wall in the next room. This way, "his interiors depict a system of rooms, which close around themselves like a labyrinth," as Görel Cavalli-Björkman notes. ${ }^{\mathrm{xl}}$ Even windows, when they are painted - most often the interior is depicted from an angle in which the windows are not directly visible (see Fig. 2) - they remain opaque; as Anne Hemkendreis observes, the windows in Hammershøi's rooms fail "to establish a system of reference between the inner and the outer world." ${ }^{\prime x i}$ The windows are like semipermeable membranes, which let light in but thwart the gaze from seeing outside (see Fig. 1). Even if, on rare occasions, the window does disclose the outside, there is a brick wall immediately behind the window blocking the gaze, as in D ust M otes D ancing in the Sunbeams (1900). Hemkendreis illustrates this this exclusion of exteriority by comparing Hammershøi's Sleeping Room (1890) with Caspar D avid Friedrich's compositionally similar W oman at the W indow (1822), in which a communication with the outside forms a crucial element of the painting's overall effect, whereas in Hammershøi's case the inside and the outside are closed from each other. ${ }^{\text {xli }}$ Similarly, Hammershøi's use of windows could be contrasted to that of Edward Hopper, another famous painter of silence, whose numerous depictions of people at a window - I'm thinking of paintings like Summer in the City (1950), M orning Sun (1954), and W oman in the Sun (1961) - establish a view to the outside, which endow the otherwise melancholic atmosphere with a sense of release. By excluding the 
viewer from penetrating the interior, Hammershøi creates a feeling of being imprisoned within the serene apartment, whose toned-down atmosphere begins to resemble that of a grave. The interiors create a feeling something akin to Mark Rothko's experience of Michelangelo's Laurentian Library, which "makes the viewer feel that they are trapped in a room where all the doors and windows are bricked up, so that all they can do is to butt their heads forever against the wall." "liii "The interiors close around the viewer, making it difficult for the viewer to distance themselves from the pictorial space. This way the exteriority of the paintings breaches the interiority of the viewer: I do not remain an external onlooker but become as if enclosed within the airtight interior itself.

H eavy atmosphere. Though Hammershøi's interiors are rather minimalist, they are still haunted by an elusive, oppressive presence. There is a peculiar heaviness in this emptiness, as if the light filling the rooms had acquired density. As Poul Vad points out, Hammershøi, unlike the Impressionists, does not identify light and colour with each other. Thus in his interiors light is not something immaterial and in itself invisible, showing itself in the colours it lights up, but rather something that concretely fills the room. ${ }^{\text {xliv }}$ I credit much of this effect to Hammershøi's characteristic brush-strokes. Hammershøi paints with short, stubby strokes and does not efface the traces of single strokes even on monochrome surfaces. The result is that the colour fields have subtle variations, which create a sense of static reverberation (see Fig. 1 and 2). Since the rooms are otherwise very toned-down and stripped, the slightly nervous buzzing of the brushstrokes fills the pictorial space with an intangible density. This heaviness adds to the suffocating effect of the hermetic pictorial space, increasing the smothering feeling of the enclosed rooms. What is interesting is that this density, much like Levinas's il y a, is not localizable or reducible to any of the depicted objects - rather, the presence can be described, as Levinas describes the night, as an "atmosphere of presence, [... ] a density of the void, a murmur of silence." ${ }^{\text {xlv }}$ This heaviness of the light, like the night, trumps intentionality: there is "something" permeating Hammershøi's rooms that can be felt but not taken as an object of intentionality. Instead, in keeping with the breaching of the viewer's interiority, the paintings seem to invert the direction of the gaze: there's not only the viewer looking at the painting, but there's also a strong feeling of being looked back by the rooms themselves. ${ }^{\text {xlvi }}$

A nonymity. Though Hammershøi paints his own apartment, there are hardly any signs of life present in the paintings. The painter removes all anecdotal material so often associated with other interior painters of the time and shows only the stage without a story. The rooms feel deserted, as if they were waiting for someone to inhabit them. The colour palette is muted, ranging mainly in different shades of grey and brown, as if livelier colours had faded away. When compared, for instance, with Carl Larsson's images of his home at Sundborn, brimming with life and laughter, Hammershøi's apartment looks like an empty husk of a home. It is a home, which has become un-homely, unheimlich. Like the insomniac's bedroom in Levinas's descriptions, the apartment is filled with a present absence, which no longer facilitates dwelling. 
Sometimes strange details, like a table pushed against a door (as in Tate's Interior, 1899), or paintings hung high almost to the ceiling (Fig. 2), highlight the enigmatic atmosphere. Sometimes a mysterious woman, dressed in black, lingers isolated in the apartment (Fig. 1). She remains withdrawn, her back usually turned toward the viewer. Whereas in D utch interior paintings, which highly inspired Hammershøi, the female figure is usually depicted doing something - playing an instrument, reading a letter, making lace - the woman's activity in Hammershøi's paintings remains meaningless. ${ }^{\text {dvii }}$ The viewer is offered no access to her identity, her intentions, or hopes - she is just there, present. She makes no contact with the viewer, nor does she interact with her surroundings. "Her presence is a complete vegetative state," Vad notes. dviii Paradoxically, her presence offers no intersubjective support that would efface the suffocating stagnation or explain the strangeness of the situation; instead, she only adds to the solitude and anonymity of the interior, highlighting the fact that the viewer's wish to crack open the mystery of the situation and catch up with the movement of life remains forever unsatisfied.

Stagnation of time. The Norwegian painter Ida Lorentzen has accurately described Hammershøi's interiors as paintings of waiting. ${ }^{\text {xli }}$ Indeed, the rooms seem to be stuck in time, held in pure duration without future. They portray an eternal, infuriating patience, as the empty rooms are filled with a foreboding that no amount of waiting will resolve: there is a feeling that something is about to happen, but what - the paintings never tell. Time stands still, nothing moves, except the non-localizable and unthematizable reverberation of light and dust dancing in its rays. The rooms seem to be held in time, quite in the same way as in Levinas's thinking the temporality of a solitary subject is "a frozen instant, where the objects of the world become like a winter landscape frozen in place."1 So, if Cézanne paints the birth of the world, as Merleau-Ponty claims, then Hammershøi paints its stagnation; if the Impressionists attempt to capture an instant in its ethereal fluidity, Hammershøi slows the instant to a halt. The pictorial means by which he achieves this effect are difficult to pinpoint. The primary factor is that there is practically no movement in the images. There are no cues about what is happening, no story to be told, nor is there such interaction between the depicted objects that would endow the picture plane with a sense of temporal order. Even the woman in black most often just stands or sits motionless. The interior simply is, without any visual hints of temporal unfolding towards the future.

A dding up nothing. By way of summary, let me draw the parallels between Levinas's descriptions of the il y a and the experience of Hammershøi's interiors. Earlier I outlined the Levinasian experience of nothingness as entailing 1) haunting, anonymous presence, which 2) severs the subject from intersubjective ties and chains them to their solitude, thereby 3) rendering them passive and incapable of escaping the suffocating nothingness and 4) breaching their interiority, making them aware of their enchainment to being as well as 5) stopping the unfolding of time towards the future and encapsulating the subject in pure duration without releasement. By analysing various pictorial means by which 
Hammershøi composes his interiors, I identified the central ways these paintings effectuate an analogous experience of impersonal, non-objectifiable, and static presence. I argued that though their tranquillity surely does not amount to the dramatic horror of Levinas's insomnia, the interiors induce an existential mood highly resembling the Levinasian experience of nothingness. Hammershøi paints his apartment and nothing more, and thereby he executes an enigmatic feat: by painting solely "the visible and the concrete," he also manages to paint something that haunts this visibility and concreteness as the excess of their presence - something that turns out to be nothing. The paradox of Hammershøi's interiors, and perhaps the very source of their captivation, lies in their uncanny ability to conjure the menacingly invisible simply by capturing the visible in paint.

\section{References}

Backman, J. 2015. C omplicated Presenœ: H eidegger and the Postmetaphysical U nity of Being. Albany, NY: SUNY Press.

Breslin, J. E. 1993. M ark Rothk o: A Biography. Chicago: The University of Chicago Press.

Cavalli-Björkman, G. 1999. "Såsom i en spegel. Vilhelm Hammershøi och det holländska interiörmåleriet." In L. Boëthius and G. Cavalli-Björkman (ed.) V ilhelm Hammershøi, pp. 20-25. Stockholm: Nationalmuseum.

Cohen, R.A. 2006. "Levinas: thinking least about death - contra Heidegger," International Journal for Philosophy of R eligion, 60(1): 21-39.

Cools, A. 2005. "Revisiting the Il y a: Maurice Blanchot and Emmanuel Levinas on the Question of Subjectivity," Paragraph, 28(3): 54-71.

Critchley, S. 1996. "Il y a - holding Levinas's hand to Blanchot's fire." In C. Bailey Gill (ed.) M aurice Blanchot: The D emand of W riting, pp. 108-122. London: Routledge.

Critchley, S. 1997. V ery little... almost nothing: death, philosophy, literature. London: Routledge.

Heidegger, M. 1976. G esamtausgabe, Bd. 2: Sein und Zeit. Frankfurt am Main: Vittorio Klostermann.

Hemkendreis, A. 2016. "Inner and Outer Realms: O paque Windows in Vilhelm Hammershøi's Interior Paintings." In E. Lajer-Burchart and B. Söntgen (ed.) Interiors and Interiority, pp. 297-311. Berlin: De Gruyter. 
Iyer, L. 2001. "The Sphinx's G aze: Art, Friendship, and the Philosophical in Blanchot and Levinas," The Southern Journal of Philosophy, 39(2): 189-206.

Kosoi, N. 2005. "Nothingness Made Visible: The Case of Rothko's Paintings," A rt Journal, 64(2): 20-31.

Large, W. 2002. "Impersonal existence: A conceptual genealogy of the 'there is' from Heidegger to Blanchot and Levinas," A ngelaki, 7(3), 131-142.

Levinas, E. 1948. "La réalité et son ombre," Les T emps M odernes 38: 769-789.

Levinas, E. 1964. "La signification et le sens,” Revue de Métaphysique et de M orale, 69(2): 125-156

Levinas, E. 1971. Totalité et infini: E ssai sur l'ex tériorité. Kluwer Academic.

Levinas, E. 1978. Ex istence and E xistents. Pittsburg, PA: D uquesne University Press.

Levinas, E. 1982. D e l'évasion. Fata Morgana.

Levinas, E.1983. L e temps et l'autre. Paris: Presses Universitaires de France. 10 édition Q uadrige: 2011.

Levinas, E. 1987. Time and the 0ther. Pittsburgh, Penn.: D uquesne University Press.

Levinas, E. 1993. D ieu, la mort et le temps. Éditions Grasset \& Fasquelle.

Levinas, E. 2000. G od, D eath, and Time. Stanford, California: Stanford University Press.

Levinas, E. 2013. De l'ex istence à l'ex istant. Seconde édition augmentée. Paris: Libraire Philosophique J. Vrin.

Lorentzen, I. 2005. "Mitt møte med Vilhelm Hammershøi." In I. Lorentzen and B. Scavenius (ed.) D en forunderlige stillheten: Ida L orentzen, V ilhelm H ammershøi, pp 15-20. Stiftelsen Modums Blaafarveværk.

Maldiney, H. 2003. A rt et ex istence. Paris: K lincksieck.

Maldiney, H. 2000. ouvrir le rien, l'art nu. encre marine.

Monrad, K. 1999. "D en intensive frånvaron. Vilhelm Hammersøi och hans konst." In L. Boëthius and G. Cavalli-Björkman (ed.) V ilhelm H ammershøi, pp. 6-19. Stockholm: Nationalmuseum.

Sartre, J.-P. 1947. L 'Ê tre et le néant. Paris: G allimard.

Sealey, K. 2013. "The 'face' of the il y a: Levinas and Blanchot on impersonal existence," Continental Philosophy Review, 46(3): 431-448.

Severson, E. 2013. L evinas's Philosophy of T ime: G ift, Responsibility, D iachrony, H ope. Pittsburgh, PA: D uquesne University Press. 
Thomson, I. 2010/ 2015. "Heidegger's Aesthetics". Stanford Encyclopedia of Philosophy. First published 2010, substantive revision 2015. https:/ plato.stanford.edu/ entries/ heidegger-aesthetics/ (accessed 8 March 2018)

Thomson, I. 2011. H eidegger, A rt, and Postmodernity. New Y ork: Cambridge University Press.

Vad, P. 1988. H ammershøi: V ark og liv. Copenhagen: Gyldendal.

Weiss, J. 1998. “Rothko's Unknown Space”. In J. Weiss (ed.) Mark Rothk o, pp. 302-330. New Haven \& London: Yale University Press.

${ }^{i}$ Levinas, G od, D eath, and T ime, 70; Levinas, D ieu, la mort et le temps, 82: "L e néant a défiéla pensée occidentale." Emphasis original.

ii See Sartre, Being and N othingness, chapter 1: "The Origin of Negation."

iii Weiss, "Rothko's Unknown Space," 322-323.

iv See Heidegger, Sein und Z eit, §40 and §51.

${ }^{\vee}$ Heidegger, Sein und Z eit, §53.

${ }^{v i}$ Kosoi, “Nothingness Made Visible: The Case of Rothko's Paintings," 22.

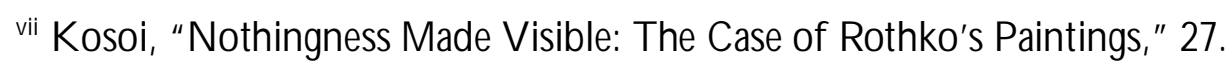

viii Kosoi, "Nothingness Made Visible: The Case of Rothko's Paintings," 30-31.

ix Thomson, "Heidegger's A esthetics," 84-90; Backman, Complicated Presence, 115-116, 129-130.

×Thomson, "Heidegger's A esthetics," chapter 3.4; Thomson, H eidegger, A rt, and Postmodernity, 90-99

${ }^{\rtimes}$ This perspective can be found also from Henri Maldiney's philosophy of art, which contains perhaps the most sustained discussions of the relationship between nothingness and painting in contemporary phenomenology. See for example Maldiney's books A rt et ex istence (1985) and ouvir le rien, l'art nu (2000).

xii Levinas, G od, D eath, and Time, 70; Levinas, D ieu, la mort et le temps, 82: "D ans la mort, néant pur, sans fondement, ressentie plus dramatiquement, avec l'acuité de ce néant plus grande dans la mort que dans l'idée de néant de l'être (dans l'il y a qui blesse moins que la disparation), nous arrivons à quelque chose que la philosophie européenne n’a pas pensé." Emphasis mine.

xiii Levinas, T ime and the 0 ther, 46-47; Levinas, L e temps et l'autre, 25-26: "Imaginons le retour au néant toutes choses, êtres et personnes. Allons-nous rencontrer le pur néant ? Il reste après cette destruction imaginaire de toutes choses, non pas quelque chose, mais le fait qu'il y a. L'absence de toutes choses, retourne comme une présence: comme le lieu où tout a sombré, comme une densité d'atmosphère, comme une plénitude du vide ou comme le murmure du silence. Il y a, après cette destruction des choses et des êtres, le 'champ de forces' de l'exister, impersonnel. Q uelque chose qui n'est ni sujet, ni substantif. Le fait de l'exister qui s'impose, quand il n'y a plus rien. [... ] Il y a comme l'irrémissibilité de l'exister pur." Translation modified. 
xiv Large, "Impersonal existence: A conceptual genealogy of the 'there is' from Heidegger to Blanchot and Levinas," 131, 137.

xv Levinas, "La signification et le sens," 154: “[... ] si, par conséquent la trace n'appartient pas à la phénoménologie - à la compréhension de l'apparaitre et du se dissimuler, on pourrait, du moins, en approcher par une autre voie, en situant cette signifiance à partir de la phénoménologie qu'elle interrompt."

xvi Levinas, T otalité et infini, 112-117; Levinas, L e temps et l'autre, 40-46.

${ }^{\text {xvii }}$ In an early essay $0 \mathrm{n}$ E scape (D el'évasion, published 1935), Levinas develops an account of consciousness based this movement of escape. Levinas argues that the very transcendence of consciousness towards the world is at its basis a flight from the fact that I am riveted to my existence: transcendence is, in fact, "ex cendence" in the face of having to exist.

xviii Levinas, L e temps et l'autre, 27-28; Levinas, D e l'ex istence à l'ex istant, 95-98.

xix Levinas, D e l'ex istence à l'ex istant, 96.

${ }^{x x}$ Levinas, E x istence and E x istents, 53; Levinas, D el'ex istenœà l'ex istant, 82: “[... ] un champ de force, comme une lourde ambiance n'appartenant à personne [... ]."

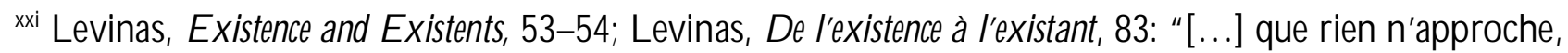
que rien ne vient, que rien ne menace: cette silence, cette tranquillité, ce néant de sensations constituent une sourde menace indéterminée, absolument. [... ] Il n'y a pas d'être déterminé, n'importe quoi vaut pour n'importe quoi. D ans cette équivoque se profile la menace de la présence pure et simple, de l'il y a."

xxii Levinas, E xistence and E x istents, 58; Levinas, D e l'ex istence à l'ex istant, 88: "L'horreur de la nuit, en tant qu'expérience de l'il y a, ne nous révèle donc pas un danger de mort, ni même un danger de douleur. Point essentiel de toute cette analyse. Le néant pur de l'angoisse heideggerienne, ne constitue pas l'il y a. Horreur de l'être opposée à l'angoisse du néant; peur d'être et non point pour l'être; être en proie, être livré à quelque chose qui n'est pas un 'quelque chose.' La nuit dissipée au premier rayon du soleil, l'horreur de la nuit ne se définit plus. Le 'quelque chose' apparait 'rien.'”

xxiii Levinas, E x istence and E x istents, 84; Levinas, D e l'ex istence à l'ex istant, 121: "L'hypostase, en participant à l'il y a, se retrouve comme solitude, comme le définitif de l'enchaînement d'un moi à son soi."

xxiv Levinas, L e temps et l'autre, 55-58; Levinas, D e l'ex istence à l'ex istant, 132-133, 135-136; Levinas, T otalité et infini, 260, 265-267. See also Cohen, "Levinas: thinking least about death - contra Heidegger," 27-29, 34-35.

${ }^{x x v}$ Levinas, Time and the 0 ther, 48-49; Levinas, L e temps et l'autre, 27: "une vigilance, sans recours possible au sommeil"

xxvi Sealey, "The 'face' of the il y a: Levinas and Blanchot on impersonal existence," 438.

xxvii Levinas, Time and the 0 ther, 71; Levinas, L e temps et l'autre, 57-58: "L'être pour la mort, dans l'existence authentique de Heidegger, est une lucidité suprême et, par là, une virilité suprême. C'est l'assomption de la dernière possibilité de l'existence par le $\mathrm{D}$ asein, qui rend par conséquent possible le fait même de saisir une possibilité, c'est-à-dire l'activité et la liberté. La mort est, chez Heidegger, événement de liberté, alors que, dans la souffrance, le sujet nous semble arriver à la limite du possible. Il se trouve enchaîné, débordé et en quelque manière passif." 
xxviii Severson, L evinas's Philosophy of Time, 45-46.

xxix Levinas, E x istence and Ex istents, 52; Levinas, D e l'ex istence à l'ex istant, 81: "L'il y a transcende en effet l'intériorité comme l'extériorité dont il ne rend même pas possible la distinction. Le courant anonyme de l'être envahit submerge tout sujet, personne ou chose. La distinction sujet-objet à travers laquelle nous abordons les existants n'est pas le point de départ d'une méditation qui aborde l'être en général."

${ }^{\mathrm{xxx}}$ Large, "Impersonal existence: A conceptual genealogy of the 'there is' from Heidegger to Blanchot and Levinas," 138.

xxxi Levinas, D e l'ex istence à l'ex istant, 96.

xxxii For instance, in the beginning of $T$ ime and the 0 ther Levinas says "The aim of these lectures is to show that time is not the achievement of an isolated and lone subject, but that it is the very relationship of the subject with the 0 ther" (Levinas, Time and the 0 ther, 39). The original passage (Levinas, L e temps et l'autre, 17) reads: "Le but de ces conférences consiste à montrer que le temps n'est pas le fait d'un sujet isolé et seule, mais qu'il est la relation même du sujet avec autrui." E ric Severson (2013) has argued that this aim permeates the whole of Levinas's philosophy.

xxxiii Levinas, L e temps et l'autre, 31-34; Levinas, De l'existence à l'existant, 106 - 117; Severson, L evinas's Philosophy of Time, 55-61.

xxxiv Critchley, "Il y a - holding Levinas's hand to Blanchot's fire"; Critchley, V ery little... almost nothing; Iyer, "The Sphinx's Gaze: Art, Friendship, and the Philosophical in Blanchot and Levinas"; Cools, "Revisiting the Il y a: Maurice Blanchot and Emmanuel Levinas on the Question of Subjectivity"; Sealey, "The 'face' of the il y a: Levinas and Blanchot on impersonal existence."

xxxv Levinas briefly discusses art in in the section on "Exoticism" in E x istence and E x istents (pp. 73 - 80 in the French original, pp. 45 - 51 in the English translation) and then later in Reality and its Shadow (L a réalité et son ombre, 1948). As Kris Sealey points out, at times Levinas seems to associate the experience of art with the il y a, while at the same time he argues that art offers precisely a refuge from the il y a. See Sealey, "The 'face' of the il y a: Levinas and Blanchot on impersonal existence," 434-435.

xxxvi Cavalli-Björkman, "Såsom i en spegel. Vilhelm Hammershøi och det holländska interiörmåleriet," 20; Monrad, "D en intensive frånvaron. Vilhelm Hammersøi och hans konst," 9.

xxxvii Vad, H ammershøi, 190-192; Cavalli-Björkman, "Såsom i en spegel. Vilhelm Hammershøi och det holländska interiörmåleriet,"25; Monrad, "D en intensive frånvaron. Vilhelm Hammersøi och hans konst," 10.

xxxviii Vad, H ammershøi, 190, 191; Cavalli-Björkman, "Såsom i en spegel. Vilhelm Hammershøi och det holländska interiörmåleriet," 25.

xxxix For instance, already in 1907 Carl Christan Clausen described Hammershøi as "the most still and silent of all Danish painters" (af alle danske Malere den mest stille og tyste) in the journal H ver 8 D ag (Vad, $\mathrm{H}$ ammershøi, 400). Many exhibitions on Hammershøi have used the terms "silence" or "tranquillity" in their titles, for example: V ilhelm H ammershøi: P oetry of Silence (Royal Academy of London, 2008), D en forunderlige stillheten: Ida L orentzen, V ilhelm $\mathrm{H}$ ammershøi (Blaafarveværk, 2005), V ilhelm $\mathrm{H}$ ammershøi: $\mathrm{H}$ iljaisuuden maalari (Amos Anderson Art Museum, 2015), and Painting Tranquility: Masterworks of V ilhelm H ammershøi (Art G allery of O ntario, 2016).

${ }^{x l}$ Cavalli-Björkman, "Såsom i en spegel. Vilhelm Hammershøi och det holländska interiörmåleriet," 22: "Hans interiörer skildrar ett system av rum som sluter sig kring sig självt som en labyrint." 
xil Hemkendreis, "Inner and Outer Realms: Opaque Windows in Vilhelm Hammershøi's Interior Paintings", 301.

xlii Hemkendreis, "Inner and Outer Realms: Opaque Windows in Vilhelm Hammershøi's Interior Paintings", 299-301.

xliii Breslin, Mark Rothk $0,3$.

xliv Vad, H ammershøi, 196-199.

xlv Levinas, E xistence and E xistents, 59; Levinas, De l'existence à l'ex istant, 90: "[... ] l'atmosphère même de présence, [... ] comme une densité du vide, comme un murmure du silence."

xvi Paul Vad $(1988,188)$ also records an experience of being looked back by the interiors.

xlvii Vad, H ammershøi, 200-203. There are few occasions, such as Interior. Stramdgade 30 (1899) and Interior with a woman reading. Strandgade 30 (1902), where the lady is actively doing something - reading or laying the table - with her face turned toward the viewer. In these occasions the atmosphere of the paintings is decidedly different as the figure offers intersubjective identification which enlivens the otherwise passive and anonymous feeling of the interior.

xlviii Vad, $\mathrm{H}$ ammershøi, 202: "Hendes tilstedeværelse er en fuldstændig vegetativ tilstand."

xlix Lorentzen, "Mitt møte med Vilhelm Hammershøi," 15.

${ }^{1}$ Severson, Levinas's Philosophy of Time, 44. 